\title{
DISTRIBUTION OF OXACILLIN IN SERUM AND MILK OF TREATED AND UNTREATED QUARTERS IN COWS FOLLOWING INTRAMAMMARY INFUSION*
}

\author{
B.K. Bansal**, J. Hamann, I. Claessens, V. Krömker and K.B. Singh** \\ Department for Hygiene and Technology of Milk, School of Veterinary Medicine, Hannover, Germany
}

\begin{abstract}
Experience in the use of intramammary antibiotic therapy has indicated that antibiotics are absorbed from the treated quarters into systemic circulation; degrees of absorption and hence crossover of drug to untreated quarters being different for different antibiotics. To answer these questions, a study was conducted on the use of oxacillin in three lactating cows of German Black Pied breed. The health status of quarters was assessed as per IDF criteria. Two quarters of each cow were infused each with Injection Oxacillin (1000 mg of water free oxacillin sodium, from Virbac Tierarzeneimittel GmbH, Germany) two times at 24 hours interval. The milk and blood samples were collected and processed in pre-treatment phase to rule out any antibiotic contamination. In post-treatment phase milk samples were collected up to 11 regular milking, and blood samples at different time intervals starting from 10 minutes to 24 hours post-therapy. The estimation of drug in milk and serum was done by Charm II test (From Charm Sciences Inc., USA). The therapy produced a drug concentration in milk from treated quarters, of $53.21 \mu \mathrm{g} / \mathrm{ml}$ to $180.55 \mu \mathrm{g} / \mathrm{ml}$ at first milking post-drug administration. The milk drug levels at 2 nd milking ranged between 0.95 and $3.83 \mu \mathrm{g} / \mathrm{ml}$. In all cases, the concentration fell below the detectable level of $0.01 \mu \mathrm{g} / \mathrm{ml}$ at 6th milking in treated quarters, and at 4 th milking in bucket milk, after last infusion. The drug passed to untreated quarters; highest drug concentration being $0.65 \mu \mathrm{g} / \mathrm{ml}$, and crossover residue persisted for 24 to $36 \mathrm{~h}$ post-therapy. The total excretion of oxacillin in milk from treated quarters varied between 18.00 and $35.50 \%$ of the administered dose. The drug diffused very rapidly to the general circulation; peak serum drug levels were detected at 10 to 30 minutes post-therapy. The peak serum drug levels in different cows ranged from $0.56 \mu \mathrm{g} / \mathrm{ml}$ to $1.38 \mu \mathrm{g} / \mathrm{ml}$. The serum drug activity of 0.02 to $0.03 \mu \mathrm{g} / \mathrm{ml}$ was still maintained at $24 \mathrm{~h}$ when a second infusion was made. Following second infusion, serum drug concentrations of 0.11 to $0.18 \mu \mathrm{g} / \mathrm{ml}$ at $12 \mathrm{~h}$, and 0.02 to $0.04 \mu \mathrm{g} / \mathrm{ml}$ at $24 \mathrm{~h}$ were observed.
\end{abstract}

* Part of Ph.D. thesis work done by senior author at School of Veterinary Medicine, Hannover, and thesis submitted to Punjab Agricultural University, Ludhiana, India

** Present Address; Department of Clinical Veterinary Medicine, Punjab Agricultural University, Ludhiana, Punjab, India - 141004. 